\title{
DZIEJE KOŚCIOŁA ORMIAŃSKIEGO W POLSCE NA TLE PASTERSKIEJ DZIAŁALNOŚCI JEGO ARCYBISKUPÓW (Rys historyczny)
}

Kiedy we wrześniu 2001 r. przybył do Armenii papież Jan Paweł II, by jako pielgrzym złożyć hołd narodowi ormiańskiemu, który od siedemnastu stuleci wiąże ciągle swe dzieje $\mathrm{z}$ chrześcijaństwem, wypowiedział znamienne słowa, iż „w annałach Kościoła powszechnego na zawsze pozostanie zapisane, że mieszkańcy Armenii byli pierwszymi, którzy jako naród przyjęli łaskę i prawdę naszego Pana Jezusa Chrystusa"1. Parafrazując te słowa, możemy z poczuciem pełnej prawdy historycznej powiedzieć, iż w annałach Polski Ormianie i ich wspólnota kościelna zapisali swe najpiękniejsze dziejowe zgłoski, które dały im uprzywilejowane przez historię miejsce w Rzeczypospolitej. Niech ten niewielki rys o ich obecności na ziemiach polskich, będzie wyrazem hołdu należnego tej szlachetnej nacji.

1. Osiedlenie się Ormian w Polsce. W literaturze przedmiotu przyjmuje się, że początek liczniejszej emigracji ormiańskiej na południowo-wschodnie tereny Rzeczypospolitej miał miejsce po $1270 \mathrm{roku}^{2}$. Najpierw władca Halicza Lew Daniłowicz (1270-1301), nadał im osobną dzielnicę we Lwowie, obdarzając ich autonomią co do wyznania i zwyczajów. Przybywali oni z Krymu, gdzie mieli swoją kolonię w Kaffie, oraz z Turcji, Siedmiogrodu i Mołdawii. Osiedlali się na Podolu, Wołyniu, na Litwie i w Polsce, aż po Gdańsk. Jako znakomici kupcy opanowali z czasem szlak handlowy ówczesnego świata od Indii i Chin aż po Antwerpię, Wenecję, Hiszpanię i Skandynawię. Zasłynęli z importu towarów wschodnich, z przemysłu artystycznego. Byli zatrudniani jako tłumacze języków wschodnich i choćby przez to byli chętnie podejmowani na dworach. Te zajęcia

${ }^{1}$ Z przemówienia Jana Pawła II w Erewaniu (25 IX 2001), OsRom 141 (2001) nr 220, s. 1, thum. pol. OsRomPol 22 (2001) nr 11-12, s. 29: Wierność Ewangelii Chrystusa oparciem dla waszego narodu 3.

2 Por. J. Petrowicz, La Chiesa Armena in Polonia, Roma 1971, s. 18. Jest to podstawowe dzieło, stanowiące swoisty tryptyk obrazujący dzieje Ormian w Polsce. Pozostałe jego części to: L'unione degli Armeni di Polonia con la Santa Sede (1626-1686), Roma 1950 (Orientalia Christiana Analecta 135) oraz La Chiesa Armena in Polonia e nei paesi limitrofi, Roma 1988. 
stały się podstawą ich zamożności. Przysparzali krajom, w których się osiedlali, dobrobytu i znaczenia, często wspomagali przybraną ojczyznę finansowo i wojskowo, będąc wobec niej lojalnymi obywatelami w przeciwieństwie do innych nacji. Kiedy król Kazimierz Wielki objął w 1340 r. Ruś w swe władanie, potwierdził ich prawa i przywileje, co doprowadziło do pełnego uformowania się autonomicznej gminy ormiańskiej, mającej własnego wójta i korzystającej swobodnie z prawa magdeburskiego ${ }^{3}$. Ponadto w 1367 r. król nadał im przywilej zupełnej swobody religijnej i potwierdził utworzenie autonomicznego arcybiskupstwa we Lwowie o charakterze dyzunickim. Przywileje te ciągle rozszerzane przez następnych władców polskich stały się fundamentem rozwoju polskich Ormian ${ }^{4}$. Pierwszym ich biskupem był Owanes (Jan) (1363-1366), budowniczy wspaniałej katedry we Lwowie pod wezwaniem Bogurodzicy. Jej fundatorami byli bogaci kupcy z Kaffy oraz ormiańscy mieszczanie lwowscy.

Jaka była organizacja kościelna tej społeczności? Otóż, duchowieństwo dzieliło się wyraźnie na dwie części: diecezjalne, które po części było bezżenne oraz zakonne, żyjące według reguły św. Bazylego ${ }^{5}$. Biskupa wybierało duchowieństwo i lud większością głosów. Wybór potwierdzał król. Biskup mianował nauczycieli (wartapiedów), kaznodziejów oraz proboszczów. Znaczny wpływ na wybór duchownych i ich obsadę mieli świeccy tzw. starsi (seniores), reprezentujący znakomitych Ormian. Pod ich kontrolą pozostawał majątek kościelny i sprzęt liturgiczny. Diakoni przed przyjęciem święceń kapłańskich składali przysięgę posłuszeństwa biskupowi i starszym. Prawo sądzenia kapłana przysługiwało starszym wspólnie z biskupem, natomiast tego ostatniego osądzać miał prawo tylko katolikos.

Wspomnieliśmy już, że Ormianie w olbrzymiej swej większości byli dyzunitami, ale ich nacja we Lwowie miała także katolików, którzy pod koniec XIV wieku byli w żywym kontakcie z unickimi bazylianami ormiańskimi, mającymi swe ważne ognisko katolickie w Kaffie. Zakon ten działał w Armenii, Persji, Konstantynopolu, pozostając w łączności z patriarchą w Sis i królem Polski. Otrzymał też na przedmieściu Lwowa kościół pod wezwaniem św. Jana ${ }^{6}$. W XV wieku nikną z pola historii przechodząc na obrządek łaciński.

W 1367 r. został wybrany na lwowską stolicę biskupią Grzegorz z przydomkiem „Wielki”, potwierdzony najpierw przez króla Kazimierza Wielkiego, a potem Władysława Jagiełłę. Od 1414 r. arcybiskupem ormiańskim we Lwowie był Grzegorz II, który nawet wysłał delegację na sobór we Florencji ${ }^{7}$.

${ }^{3}$ Por. Z. Kaczmarczyk, Monarchia Kazimierza Wielkiego, Poznań 1946, t. 2, s. 118.

${ }^{4}$ Por. Cz. Lechicki, Kościót ormiański w Polsce, Lwów 1928, s. 13.

5 Por. M. Oleś, The Armenian Law in the Polish Kingdom (1350-1519), Roma 1966, s. 19-20.

${ }^{6}$ Por. W. Abraham, Powstanie organizacji Kościoła łacińskiego na Rusi, Lwów 1904, s. 354; zob. Z. Obertyński, Ormianie polscy na Soborze Florenckim, „Przegląd Historyczny” $32-33$ (19341935) 21.

7 Por. Petrowicz, La Chiesa Armena in Polonia, s. 45. 
2. Unia florencka w 1439 roku. Ważnym wydarzeniem w dziejach Ormian (nie tylko w Polsce) był Sobór Florencki. Od początku brała udział w jego obradach delegacja ormiańska, wysłana przez katolikosa z Sis Konstantyna VI. W rezultacie doszło na nim do unii Kościoła ormiańskiego z Rzymem. Ogłosił ją uroczyście papież Eugeniusz IV bullą „Exultate Deo”. Warunki unii zawierały między innymi uznanie uchwał Soboru Chalcedońskiego, zwłaszcza nauki o podwójnej naturze Chrystusa, której dotąd Kościół ormiański nie przyjmował $^{8}$. Na sobór przybyła również delegacja lwowskiego arcybiskupa Grzegorza II. Początkowo nie chciała ona przyjąć dekretu soborowego odnośnie Ormian, upierając się przy swoich tradycjach dotyczących wierzeń i obyczajów. W końcu jednak zaakceptowali unijny dekret. Papież polecił więc arcybiskupowi Grzegorzowi, by kontaktował się z mnichem Nersesem z Kaffy co do realizacji unijnych postanowień ${ }^{9}$. Niewiele jednak wiemy, jak przebiegała realizacja unii wśród polskich Ormian. Wiadomo tylko, że istniały wielkie opory odnośnie jej wprowadzenia. Wpływ na to miała wysoka duma narodowa, niechęć do Zachodu, troska o zachowanie własnych zwyczajów, a także, niestety, częste zjawisko nieuctwa kleru ormiańskiego zdanego na decyzje swoich „starszych”"10. W 1441 r. arcybiskupem Lwowa został Awedyk. Odrzucił on zwierzchnictwo katolikosa $\mathrm{z}$ Sis, podporządkowując się katolikosowi z Eczmiadzyna, który odrzucał zdecydowanie unię florencką. Nic zatem dziwnego, że należało następnym wiekom zostawić przygotowanie właściwego gruntu pod dojrzałe zjednoczenie, a dzieło to podjęte zostało później przez światłych ludzi zarówno ze strony Ormian, jak i łacinników.

\section{Zmagania lwowskich arcybiskupów ormiańskich o większą niezależność} od „starszych” w XV i XVI wieku. Rysem charakterystycznym tego okresu jest walka, jaką podjęli arcybiskupi ormiańscy z przemożną władzą „starszych” w łonie swojej wspólnoty. Panujący prawdopodobnie w latach 1461-1482 na tronie arcybiskupim we Lwowie biskup Chaczadur był osobowością słabą, podporządkowaną całkowicie „starszym” ". Ale już arcybiskup Stefan I pasterzujący wspólnocie ormiańskiej w latach 1481-1492 oraz Kilian Stepanian kierujący nią od 1515 roku, podjęli wysiłki mające na celu uniezależnienie się od władzy seniorów. Stefan pozostając w kontakcie z Kościołem katolickim, powziął nawet pielgrzymkę do Rzymu, zaś Stepanian - rodowity lwowianin - podjął długie starania, by wyeliminować „starszych” z zarządu Kościołem ${ }^{12}$. Potem kontynuował tę walkę, ze zmiennym szczęściem, arcybiskup Grzegorz III (1551-1572).

\footnotetext{
${ }^{8}$ Por. Obertyński, dz. cyt., s. 13.

${ }^{9}$ Por. tamże, s. 14.

${ }^{10}$ Por. T. Gromnicki, Ormianie w Polsce, ich historia, prawa i przywileje, Warszawa 1899, 15.

${ }^{11}$ Lata jego pasterzowania ustalał w swoich badaniach Jerzy Petrowicz, por. De Ecclesia Armena in Polonia et terris adiacentibus, ,, Antemurale” 4 (1958) 187-189.

12 Por. Petrowicz, La Chiesa Armena in Polonia, s. 74-78; Cz. Lechicki, dz. cyt., s. 40.
} 
Kiedy zaś zatwierdził go na stolicy biskupiej król Zygmunt August, wniósł skargę na ormiańskich patrycjuszy. Zarzucał w niej między innymi usuwanie przez „starszych” bez wiedzy biskupa kapłanów, samowolne uwalnianie winnych od cenzur kościelnych, trzymanie pod zamknięciem ksiąg i sprzętów kościelnych $^{13}$. Mimo dekretu ograniczającego wpływy seniorów, zatargi w łonie religijnej wspólnoty Ormian trwały nadal. Po 20 latach zmagań Grzegorz zrezygnował z urzędu, udał się do Palestyny, a potem do Rzymu, gdzie miał złożyć katolickie wyznanie wiary ${ }^{14}$. W polemice o kompetencje w kościelnej wspólnocie powoli dojrzewać zaczął grunt pod przyszłą jedność z Rzymem. Było to zarówno dziełem władzy państwowej, jak i przedstawicieli Kościoła łacińskiego oraz samego środowiska Ormian, które dobrze odczytało swój czas.

4. Okres przedunijny (1575-1624). Wokół przygotowania jedności Ormian w Polsce ze Stolicą Apostolską wiele uczynił arcybiskup Barsan Bogdanowicz. Wyświęcony w 1575 r. przez katolikosa Eczmiadzyna, został niewiele lat później uznany przez króla Stefana Batorego, do którego arcybiskup zwrócił się z prośbą o ograniczenie nadużyć ze strony „starszych” ormiańskich. Zwolennik jedności, wziął udział wraz z prawosławnymi w spotkaniu z nuncjuszem Bolognettim w sprawie recepcji kalendarza gregoriańskiego, którego jednak w tym czasie Ormianie jeszcze nie przyjęli ${ }^{15}$. Mimo krótkiego, bo zaledwie rocznego zasiadania na stolicy lwowskiej, na początku stulecia wiele zdziałał dla sprawy jedności arcybiskup Garabed. Przybył on do Lwowa z Mezopotamii, a wybrany na arcybiskupa w 1606 roku, zyskał poparcie króla Zygmunta III Wazy. Chcąc podnieść poziom duchowieństwa sprowadził ormiańskie kodeksy Pisma św., kładąc podwaliny pod przyszłą bibliotekę. W tym miejscu trzeba też wspomnieć, że na przełomie XVI i XVII wieku Kościół ormiański posiadał już dość dobrze zorganizowaną sieć parafialną. Ogólna liczba Ormian liczyła od trzech do czterech tysięcy. Istniała duża wspólnota w Kijowie, Łucku, Kamieńcu Podolskim, Jazłowcu i Tyśmienicy na Pokuciu. Wszędzie tam posiadali przynajmniej jeden kościół parafialny. We Lwowie istniały w tym czasie dwie parafie. Znaczna grupa Ormian, przybyła z Turcji i Armenii, osiedliła się w nowo powstałym Zamościu. Jan Zamoyski w 1585 r. wydał przywilej, dzięki któremu znacznie się rozwinęli i wybudowali kościół pod wezwaniem Wniebowzięcia Najświętszej Maryi Panny ${ }^{16}$.

5. Unia z Rzymem i proces jej utrwalania w XVII wieku. Jedność ze Stolicą Apostolską, która miała się okazać czymś trwałym w dziejach Kościoła ormiań-

13 Por. Lechicki, dz. cyt., s. 41.

14 Por. tamże, s. 43, przyp. 1.

15 Por. Petrowicz, dz.cyt., s. 117; S. Barącz, Żywoty sławnych Ormian w Polsce, Lwów 1856, s. 68.

${ }^{16}$ Por. J. Kowalczyk, Kościót w Zamościu w XVII wieku, ,Kwartalnik Architektury i Urbanistyki” 25 (1980) z. 3-4, 215. 
skiego w Polsce, była rezultatem zaangażowania się wielu wybitnych postaci zarówno ze strony Ormian, jak i łacinników, zwłaszcza nuncjuszy apostolskich w Polsce. Trwające kilka dziesięcioleci zmagania około dzieła jedności, nie pozbawione były napięć, dramatycznych wydarzeń w samym łonie społeczności ormiańskiej, która prowadzona konsekwentnie przez swych pasterzy, dojrzewała powoli do dziejowej roli jedności z Rzymem.

W 1626 r. przybył do Lwowa katolikos eczmiadzyński Melchizedek. Zmuszony przez Turków do opuszczenia swojej biskupiej stolicy, udał się najpierw do Konstantynopola, gdzie wobec papieskich legatów złożył hołd posłuszeństwa papieżowi. Wkrótce sam przybył do Rzymu wyrażając pragnienie zjednoczenia Ormian ze Stolicą Apostolską. Papież Paweł V postawił dwa warunki: 1. by w czasie Mszy św. używano nieco wody dla podkreślenia dwóch natur w Chrystusie, 2. przyjąć postanowienia Soboru Chalcedońskiego. Obdarował też Melchizedeka krzyżem i szatami liturgicznymi ${ }^{17}$. We Lwowie patriarcha wyświęcił na arcybiskupa Mikołaja Torosowicza, po czym wkrótce umarł. Nowy arcypasterz, mający szerokie kontakty z hierarchią łacińską, złożył w 1630 r. wyznanie wiary w kościele OO. Karmelitów we Lwowie, co wywołało gwałtowny sprzeciw seniorów i tak już wrogo nastawionych wobec osoby Torosowicza: odmówili mu wydania klucza do katedry i postanowili odbyć nad nim sąd. Tymczasem ten w porozumieniu $z$ arcybiskupem lacińskim Janem Andrzejem Próchnickim, w otoczeniu ormiańskiego duchowieństwa, w katedrze łacińskiej potwierdził uroczyście katolickie wyznanie wiary i odprawił po raz pierwszy Mszę św. w obrządku ormiańsko-unickim ${ }^{18}$. Mając poparcie łacińskiej hierarchii oraz lwowskiego magistratu, a przede wszystkim króla Zygmunta III Wazy, mógł biskup ormiański podjąć walkę z decyzjami „starszych". I rzeczywiście: straż miejska siłą otworzyła drzwi ormiańskiej katedry i wprowadziła tam Torosowicza, co oznaczało otwartą wojnę ze starszyzną nacji ormiańskiej. Zgon króla Zygmunta III w 1632 roku, a rok później arcybiskupa Próchnickiego, pozbawił pasterza polskich Ormian poparcia. Król Władysław IV i nowy łaciński arcybiskup we Lwowie Stanisław Grochowski nie okazali się jego sprzymierzeńcami. Torosowicz musiał szukać poparcia w Rzymie, dokąd udał się w 1635 r. i przed papieżem Urbanem VIII złożył raz jeszcze wyznanie katolickiej wiary ${ }^{19}$. Przed odjazdem Stolica Apostolska nadała mu paliusz, wynosząc go oraz jego następców do godności metropolitów z jurysdykcją na Polskę, Wołoszczyznę i Mołdawię 20 .

Po powrocie do Polski zabrał się arcybiskup do propagowania unii wśród swoich ziomków. Niestety, czynił to w sposób tak dalece odbiegający od przy-

\footnotetext{
17 Por. Petrowicz, L' unione degli Armeni di Polonia con la Santa Sede (1626-1686), s. 13.

18 Por. tamze, s. 24 i 40.

19 Por. Barącz, dz. cyt., s. 334

20 Por. Lechicki, dz. cyt., s. 61.
} 
jętych zasad, że wzbudził prawdziwą niechęć nie tylko u Ormian, ale zraził do siebie również kolejnych władców Polski, kilku nuncjuszy i duchowieństwo łacińskie. Taki stan napięcia trwał ponad 30 lat. Wielu Ormian zaczęło opuszczać Lwów, zgorszeni zaczęli stronić od Kościoła, szerzył się indyferentyzm religijny ${ }^{21}$. Korzystając z pobytu króla Jana Kazimierza we Lwowie, zwrócili się doń Ormianie z prośbą o przysłanie z Rzymu takich misjonarzy, którzy nie będą od unii odstręczać, ale do niej mądrze przekonywać. Wybór padł na zakon Teatynów, wśród których wybitną osobowością w tym czasie odznaczał się Klemens Galano, znający doskonale stosunki na Wschodzie i władający językiem ormiańskim. Dawało to rękojmię, że unia pozyska gorliwych apostołów. W towarzystwie ojca Alojzego Pidou przybył Galano do Lwowa w 1664 $\mathrm{roku}^{22}$. W momencie przybycia Teatynów liczba wiernych liczyła około czterech tysięcy, z tego niewielka część była unicka. Wśród nich pracowało około 23 kapłanów w 9 parafiach posiadających 15 kościołów ${ }^{23}$. Na takiej niwie rozpoczęli Teatyni swoją pracę. Wybudowali alumnat, mimo oporów ze strony arcybiskupa Torosowicza. Mieli natomiast poparcie od „starszych”, którzy zaczęli rozumieć, jaką wartość dla nacji ormiańskiej może mieć taka instytucja kształcąca ich synów. I rzeczywiście, ze szkoły tej wyszli najświatlejsi kapłani, którzy przyczynili się w istotnym stopniu do przyjęcia unii przez całą społeczność polskich Ormian. Do nich należał m. in. Wartan (Walerian) Hunanian. Upatrzony przez Rzym na koadiutora we Lwowie, został wyświęcony na biskupa w 1675 r. przez arcybiskupa Torosowicza. Niestety współpraca między nimi układała się źle. Hunanian nękany przez swego zwierzchnika opuścił Lwów i udał się do Armenii, gdzie miał pozostać blisko dziesięć lat, z tego część w więzieniu z powodu wierności unii ${ }^{24}$. W 1681 r. nastąpił zgon arcybiskupa Torosowicza. Po krótkich rządach księdza Gabriela Zachnowicza, wychowanka Teatynów, który propagował unię, administrowanie diecezją przejął inny wychowanek kolegium teatyńskiego biskup Bogdan Nersesowicz ${ }^{25}$. Będący także $\mathrm{w}$ konflikcie $\mathrm{z}$ arcybiskupem Torosowiczem postarał się o przywilej celebrowania w obrządku łacińskim. Przez jakiś czas był spowiednikiem Sióstr Benedyktynek w Jarosławiu, a dzięki poparciu księcia Dymitra Wiśniowieckiego, został proboszczem w Lubartowie. Nie zapomniał jednak o swoim pochodzeniu czyniąc wiele dla swoich braci. Zakładał szkoły dla młodzieży ormiańskiej, a nominowany na biskupa i administratora diecezji do czasu

21 Por. tamże, s. 65; zob. Petrowicz, dz. cyt., s. 83-97.

22 Por. A. Pidou, Dzieje zjednoczenia Ormian polskich z Kościołem rzymskim w XVII wieku, Warszawa 1876 (wyd. A. Pawiński, Źródła dziejowe, t. II). Jest to podstawowe dzieło mówiące w całości o działalności Zakonu Teatynów w tym okresie w Polsce.

23 Por. Petrowicz, dz. cyt., s. 118-130; Lechicki, dz. cyt., s. 69.

24 Por. Barącz, dz. cyt., s. 140; Petrowicz, dz. cyt., s. 295.

25 Z. Obertyński, Legenda Jazłowiecka, „Studia Źródłoznawcze” 7 (1962) 71-72; zob. Barącz, dz. cyt., s. 240. 
powrotu Wartana Hunaniana, zajął się gorliwie umacnianiem pasterskiej pozycji wobec seniorów ormiańskiej nacji, wyrazem czego było odebranie im symbolu władzy - kluczy od katedry. Nic dziwnego, że taka stanowcza postawa nie w smak była jego przeciwnikom. Postanowił więc usunąć się z działalności pasterskiej, wyjeżdżając do Rzymu ${ }^{26}$. Pracując w Rzymie pośród skupisk ormiańskich wydał w 1685 r. słownik łacińsko-ormiański, mający kolosalne znaczenie w krzewieniu katolicyzmu i reformie ormiańskich ksiąg liturgicznych w Polsce ${ }^{27}$.

Dzięki zabiegom papieża Innocentego XI oraz króla Jana III Sobieskiego, prawdziwego przyjaciela Ormian, wrócił z Armenii arcybiskup Hunanian. Wracając do Polski przez Mołdawię, zabrał ze sobą biskupa Menasa, który przyjął we Lwowie unię. Podobne sukcesy osiągnął w Siedmiogrodzie i na Wołoszczyźnie. W Polsce zajął się wewnętrzną pracą organizacyjną, mającą na celu utwierdzenie unii. Osadził jedyny w Europie żeński zakon Benedyktynek we Lwowie, a nade wszystko dążył do wzmocnienia karności kościelnej kleru. W tym celu zwołał we Lwowie pierwszy synod ormiański w 1691 roku $^{28}$. Dokonano na nim reformy ksiąg liturgicznych w duchu katolickim, zaprowadzono celibat księży. W 1695 r. arcybiskup Hunanian usunął się od rządów, które po dwóch latach przejął na nowo - ponaglany prośbami, by wrócił z Rzymu - biskup Nersesowicz. Kontynuował on dzieło umacniania unii. Dwukrotnie urządził zjazdy kleru diecezjalnego, na których ustalono między innymi zwoływanie kongregacji dekanalnych oraz zakładanie szkół ormiańskich. To wszystko miało służyć poprawie wewnętrznych stosunków w łonie Kościoła ormiańskiego. Dbając o wzrost życia religijnego na prowincji, konsekrował kościół w Stanisławowie, powołał do życia trzy nowe parafie: w Tyśmienicy, Horodence i Brzeżanach. Poświęcił też łaciński kościół w Krasnobrodzie, ufundowany przez królową Marię Kazimierę ${ }^{29}$. Umierając w 1709 r. pozostawił po sobie pamięć jednego z najwybitniejszych pasterzy ormiańskich. Arcybiskup Hunanian przeżył swojego koadiutora jeszcze o sześć lat, które poświęcił całkowicie dziełom miłosierdzia. Zmarł we Lwowie w 1715 roku. To dzięki niemu i biskupowi Nersesowiczowi zawdzięcza unia swoje umocnienie się w Kościele ormiańskim i zbliżenie tej nacji do kultury zachodniej.

6. Działalność biskupów ormiańskich w XVIII wieku. Jeszcze za życia arcybiskupa Hunaniana został wybrany jednomyślnie przez „starszych” i duchowieństwo na koadiutora ks. Jan Tobiasz Augustynowicz ${ }^{30}$. Ponieważ unic-

\footnotetext{
${ }^{26}$ Por. Lechicki, dz. cyt., s. 86, zwłaszcza przypis 2.

27 Por. Barącz, dz. cyt., s 240.

28 Por. Petrowicz, La Chiesa Armena in Polonia e nei paesi limitrofi, s. 12nn.

29 Por. Barącz, dz. cyt., s. 240; także Lechicki, dz. cyt., s. 92n.

${ }^{30}$ Por. D. Kajetanowicz, Augustynowicz Jan Tobiasz, w: Polski Stownik Biograficzny, Kraków 1935, t. 1, s. 185; także, J. Petrowicz, dz. cyt., s. 109nn.
} 
cy Ormianie w Mołdawii od 1715 r. zaczęli podlegać bezpośrednio metropolicie lwowskiemu, ten mianował swoim wizytatorem ks. Stanisława Roszkę, by prowadził tam dzieło umacniania unii. Natomiast sam odbył kanoniczną wizytację swojej archidiecezji, po czym udał się do Rzymu, by tam otrzymać tytuł hrabiego rzymskiego i zostać prałatem domowym papieża Klemensa XII oraz asystentem tronu papieskiego. Po powrocie z Rzymu wziął udział w bardzo ważnym synodzie ruskiego Kościoła unickiego w Zamościu w 1720 roku $^{31}$. Rok 1723 zaznaczył się dla kościoła ormiańskiego w Polsce dwoma istotnymi wydarzeniami. Najpierw zwizytował lwowską metropolię w imieniu nuncjusza Santiniego biskup Stanisław Józef Hozjusz. Miał on również uprosić u arcybiskupa Augustynowicza zgodę na przyjmowanie do kolegium teatyńskiego Rusinów na zasadzie gości. Ponadto w trakcie wizytacji zatwierdzone zostały wszystkie reformy przeprowadzone przez arcybiskupów ormiańskich zarówno wśród kleru, jak i w liturgii Kościoła ${ }^{32}$. Drugim ważnym wydarzeniem była odbudowa ormiańskiej katedry we Lwowie, zrujnowanej po pożarze w 1712 roku. Odbudową i restauracją wnętrza zajął się brat arcybiskupa Krzysztof Augustynowicz, zamożny lwowianin. Uczyniono to na modłę barokową, zakrywając starą armeńską polichromię katedry. Przy okazji odbudowano budynek klasztorny Sióstr Benedyktynek ${ }^{33}$. W 1735 r. poprosił arcybiskup o mianowanie koadiutora. Został nim synowiec metropolity Jakub Stefan Augustynowicz ${ }^{34}$. Zatwierdzony przez papieża Klemensa XII objął rządy w archidiecezji po śmierci swego stryja w 1751 roku. W trakcie swojego pasterzowania dokonał dwukrotnej wizytacji archidiecezji w 1762 r. i dziesięć lat później, już po zajęciu Małopolski przez Austrię. Według relacji z pierwszej wizytacji wynikało, że archidiecezja obejmowała obszar Polski, Litwy, Wołoszczyzny i Mołdawii. Wszyscy księża w liczbie 41 byli celibatariuszami i wywodzili się z teatyńskiego kolegium ${ }^{35}$. Wraz z zajęciem przez Austrię Małopolski wschodniej ustaje pomyślny rozwój unii ormiańskiej. Kościołowi i jego pasterzom przyszło dostosować się do nowych warunków politycznych i kościelnych.

7. Okres józefinizmu. Prawdziwą zasługą arcybiskupa Augustynowicza po pierwszym rozbiorze Polski było uzyskanie u nowych władz austriackich za-

${ }^{31}$ Synod ten odbyty pod przewodnictwem nuncjusza Grimaldiego i metropolity Leona Kiszki stanowił końcowy etap w utrwaleniu unii brzeskiej, zob. Cz. Lechicki, dz. cyt., s. 97.

32 Por. J. Petrowicz, dz. cyt., s. 130.

33 O katedrze tej znakomitą pracę napisał ostatni rządca Kościoła ormiańskiego jako jego wikariusz kapitulny, ks. D. Kajetanowicz, skazany przez władze sowieckie na 10 lat zesłania, gdzie zmarł w 1954 roku w Abreź w pobliżu koła podbiegunowego, zob. Katedra ormiańska i jej otoczenie, Lwów 1930.

34 Por. Kajetanowicz, Augustynowicz Jakub Stefan, w: Polski Stownik Biograficzny, t. 1, s. 185.

35 Por. Petrowicz, dz. cyt., s. $183 \mathrm{nn}$. 
bezpieczenia materialnego dla arcybiskupa i kleru diecezjalnego, które często żyło na granicy ubóstwa. Dzięki pozytywnej opinii gubernatora Pergena i wstawiennictwu nuncjusza Viscontiego, wszechwładny kanclerz Kaunitz przyznał stałe uposażenie w wysokości 2000 florenów dla arcybiskupa i 1400 dla wikariuszy katedralnych we Lwowie ${ }^{36}$. Oprócz tego arcybiskup odnowił katedrę po ponownym pożarze i zarządził dla całej archidiecezji używanie kalendarza gregoriańskiego; zmarł we Lwowie w 1783 roku.

Pod rządami nowego arcypasterza Jakuba Waleriana Tumanowicza Kościół ormiański dostał się w tryby szalejącego józefinizmu ${ }^{37}$. Skasowano od razu pięć parafii, zburzono dwa kościoły we Lwowie (św. Anny i św. Jakuba), zaś kościół św. Krzyża przerobiono na wojskową kaplicę więzienną. Ponadto ograniczono liczbę księży do 14 i tylko połowa z nich uzyskała utrzymanie. Zamknięto też kształcące przez tyle lat młodzież ormiańską kolegium teatyńskie i przerobiono je na koszary wojskowe. Tak oto po 120 latach ta zasłużona dla kultury zachodniej placówka zniknęła. Ostał się tylko konwent Benedyktynek, który odwiedził osobiście w 1784 r. cesarz Józef II, zarządzając jednocześnie ograniczenie liczby zakonnic i nakazując zgromadzeniu zajmowanie się sprawami czysto użytecznymi, z pominięciem kontemplacji. Arcybiskupowi, mimo tak niesprzyjających warunków, udało się jednak zadbać o potrzeby religijne wiernych ormiańskich. Przeprowadzał wizytację archidiecezji, konsekrował szereg kościołów, wysyłał misjonarzy na Krym i Bukowinę; zmarł w 1798 r. nie zostawiając następcy ${ }^{38}$.

Rok później rządy objął wybrany przez duchowieństwo i zatwierdzony przez cesarza Jan Jakub Symonowicz ${ }^{39}$. Zajął się gorliwie zarządem archidiecezji, a zwłaszcza tych jej terenów, które znajdowały się pod zaborem rosyjskim. W tym celu wyświęcił na biskupa ks. Józefa Krzysztofowicza, który za zgodą cara Aleksandra I osiadł w Mohylowie. Zadbał też Symonowicz o kanoniczną erekcję swojej kapituły i należyte jej uposażenie. Jako dziekan Wydziału Teologicznego w ówcześnie niemieckim uniwersytecie we Lwowie, a potem tzw. liceum, dbał o podniesienie poziomu nauczania i o promowanie polskich uczonych ${ }^{40}$. Ujemną stroną jego rządów był fakt dobrowolnej zgody na polecenie rządu austriackiego z 1812 roku, o przechodzeniu zdolnych kapłanów ormiańskich na obrządek łaciński. Mimo to jego szesnastoletnie rządy przyniosły wiele dobrego dla całej archidiecezji; zmarł w 1816 roku.

\footnotetext{
${ }^{36}$ Por. Lechicki, dz. cyt., s. 106.

37 Por. J. Wysocki, Tumanowicz Jakub Walerian, SPTK IV 352-353; zob. Petrowicz, dz. cyt., s. $215 \mathrm{nn}$.

38 Por. Petrowicz, dz. cyt., s. 238.

39 Por. Lechicki, dz. cyt., s. 114.

40 Jednym z nich był wybitny historyk Kościoła, Ormianin z pochodzenia, ks. F. Zachariasiewicz, autor Wiadomości o Ormianach w Polszcze, Lwów 1842.
} 
8. W XIX wieku. Stulecie to dla Kościoła ormiańskiego stało pod znakiem pasterzowania dwóch wielkich duchownych. Jeden z nich to Samuel Stefanowicz, który zdołał zrzucić z Kościoła jarzmo józefinizmu, a drugi - arcybiskup Isak Mikołaj Isakowicz potrafiący swoją pracą zjednać sobie miłość współbraci, szacunek łacinników i greko-katolików. Ich rządy poprzedził arcybiskup Kajetan Augustyn Warteresiewicz. Był to człowiek światły, bibliofil, któremu udało się zgromadzić znaczny księgozbiór. Dbał o regularne dochody dla duchowieństwa i zakonnic, a swój osobisty majątek przeznaczył na odnowienie katedry lwowskiej. Kontynuował również misje między Ormianami na Bukowinie; zmarł w 1831 roku $^{41}$.

Nikt nie przypuszczał, że jego następca, podeszłego już wieku Samuel Cyryl Stefanowicz, tak energicznie i udanie będzie kierował archidiecezją, że zyska sobie powszechne uznanie. Wielokrotnie wizytował parafie, co zbliżyło go do wiernych, wydawał liczne listy pasterskie, w których poruszał problemy, jakie zauważył w trakcie wizytacji. Zajął się obsadą nowej parafii w Czerniowcach, a w Suczawie wyznaczył kapelana dla Ormian unitów. Pod jego rządami rozwinął się bank diecezjalny i konwent Sióstr Benedyktynek. Powiększyła się liczba duchowieństwa, z którym arcybiskup utrzymywał serdeczny kontakt. Wzrósł poziom intelektualny, stanowiący wyróżnik ormiańskiego kleru. Mimo stu pięciu lat życia arcybiskup obywał się bez sufragana i dopiero papież Pius IX wyznaczył mu go w osobie ks. Grzegorza Michała Szymonowicza; zmarł w $1858 \mathrm{r}$. w wieku 107 lat $^{42}$.

Nominowany przez papieża arcybiskup objął rządy przy niezbyt przychylnych dla obrządku ormiańskiego głosach postulujących jego zniesienie. Kres tym pogłoskom położył sam papież zaznaczając wyraźnie, że ma on trwać nadal $^{43}$. Z energią przedsięwziął Szymonowicz wszechstronną działalność nie tylko duszpasterską. Kontynuował dalszą odnowę katedry, wybudował kaplicę we Lwowie ku czci poległych powstańców styczniowych, ufundował internat dla młodych Ormian z inicjatywy doktora Józefa Torosiewicza. Administracja i kierownictwo zakładu spoczywało w rękach kapituły ormiańskiej we Lwowie. W 1869 r. arcybiskup wziął udział w obradach Soboru Watykańskiego I, otrzymując w Rzymie od papieża tytuł asystenta tronu papieskiego. Zmarł w 1875 roku, a rządy w archidiecezji objął na pięć lat Grzegorz Józef Romaszkan. Zdołał on w tym czasie zadbać o lepsze uposażenie duchowieństwa i poświęcić nowy kościół w Czerniowcach ${ }^{44}$.

Po jego śmierci w 1881 r. duchowieństwo ormiańskie wybrało na swego arcybiskupa Isaka Mikołaja Isakowicza. Już wcześniej dał się poznać jako

\footnotetext{
${ }^{41}$ Por. Petrowicz, dz. cyt., s. 282.

${ }^{42}$ Por. tamze, s. 298nn.

43 Por. Lechicki, dz. cyt., s. 130nn.

${ }^{44}$ Por. Petrowicz, dz. cyt., s. 333-343.
} 
znakomity kaznodzieja, doskonały polemista z wrogami Ormian i gorliwy propagator katolicyzmu na Bukowinie. Zresztą wśród całej nacji ormiańskiej, za jego rządów doskonale rozwijało się duszpasterstwo. Wspomniany już zakład im. Torosiewicza liczył 47 uczniów i ciągle rozszerzał swoją działalność. Podobnie rzecz się miała z konwentem Sióstr Benedyktynek i bankiem diecezjalnym. Sam arcybiskup miał doskonałe stosunki z Rzymem. Papież Leon XIII mianował go prałatem domowym i hrabią rzymskim. Podobne wzięcie miał na dworze cesarskim w Wiedniu. Franciszek Józef I mianował go tajnym radcą, z tytułem ekscelencji. Liczne listy pasterskie, patriotyczne kazania, piękna polszczyzna, zaskarbiły mu nie tylko przydomek ,złotoustego”, ale co ważniejsze, serca zarówno Ormian, Polaków jak i Rusinów. Otoczony powszechnym szacunkiem zmarł w 1901 roku $^{45}$.

Warto w tym miejscu jeszcze przypomnieć, jaką sieć parafialną posiadała archidiecezja ormiańska na początku XX wieku. Jej rozwój był oczywiście wynikiem osadnictwa Ormian w Polsce i dlatego parafie powstawały tu od XIV do XVIII wieku. Fundatorami było najczęściej mieszczaństwo ormiańskie i magnateria polska. Charakterystyczną cechą był fakt, że większość parafii znajdowała się w województwie ruskim i podolskim. Na ogólną liczbę sześciu tysięcy Ormian, parafie były w Brzeżanach, Czerniowcach, Horodence, Jazłowcu, Kamieńcu Podolskim, Kutach, Lwowie, Łucku, Łyścu, Mohylowie Podolskim, Obertynie, Raszkowie, Śniatyniu, Stanisławowie, Suczawie, Tyśmienicy, Warężu, Zamościu, Złoczowie i Żwańcu ${ }^{46}$.

Taki stan archidiecezji zastał arcybiskup Józef Teofil Teodorowicz (18641938), gdy obejmował w $1901 \mathrm{r}$. lwowską stolicę ormiańską ${ }^{47}$. Ten wielki Polak, syn narodu ormiańskiego, zapisał się złotymi zgłoskami w dziejach obu tych nacji. Tak wiele dokonał około przywrócenia Polski na mapę Europy, tak wiele pasterskiego trudu włożył w kształtowanie ducha obu narodów, że czytelnik niniejszego artykułu zechce zapewne sam sięgnąć po prace tylko jego osobie poświęcone.

${ }^{45}$ Por. Lechicki, dz. cyt., s. 136nn; zob. J. Bazydło, EK VII 497-498.

${ }^{46}$ Por. Petrowicz, dz. cyt., s. 352 nn.

${ }^{47}$ Por. L. Grzebień, Teodorowicz Józef Teofil, SPTK VII 307-311; P. Stach, Arcybiskupa Teodorowicza działalność na polu biblijnym, AK 39 (1947) t. 47, 449-456; 40 (1948) t. 48, 77-82, 182-184. 


\section{HISTORY OF THE ARMENIAN' CHURCH IN POLAND}

\section{(Summary)}

This article shows eight centuries of Polish Armenians' history. Peaceful coexistence between the Armenian nation and Polish people, who represented western culture, resulted in the catholic union with the Apostolic See, which appeared to be solid. Armenian archbishops rendered a great service to consolidate the union. Most of the them were great patriots, who merged perfectly Armenian tradition and heritage with Polish culture. 